\title{
Indonesian Islamic Banking Performance: A Conceptual Framework
}

\author{
Ruspita Rani Pertiwi ${ }^{1 *}$, Jann Hidajat Tjakraatmadja ${ }^{2}$, Hary Febriansyah ${ }^{3}$ \\ ${ }^{*}$ Corresponding author
}

\begin{abstract}
This conceptual paper aims to develop an integrated organizational performance model. The analysis will focus on the role of organizational management variables using Indonesian Islamic banking as a case study and features a correlation between how they manage their performance. The model developed in this paper uses a conceptualization phase adapted from Dubin's theory-building method. The conceptualization phase formed through interviews, observations, written expert experiences, and research publications. The finding proposes a conceptual framework that has the potential to boost organization performance by pay attention to how to bring together service innovation, knowledge management capability, and human capital drivers in such a model. The findings provide valuable insights for organizations into non-financial variables' role and the importance of organizational management variables in improving organizational performance, which could help them in (re-) align their management practices and formulating strategies for Indonesian Islamic banking.
\end{abstract}

Keywords: organizational performance, Islamic banking, model development

JEL Classification: L2, L8

\begin{abstract}
Abstrak. Paper konseptual ini bertujuan untuk mengembangkan model kinerja organisasi yang terintegrasi. Analisis akan fokus pada peran variabel organisasi manajemen. Paper ini menggunakan Perbankan Syariah Indonesia sebagai studi kasus dan menampilkan korelasi cara mereka mengelola kinerja mereka. Pengembangan model dalam paper ini menggunakan "konseptual fase" yang diadaptasi dari metode pengembangan teori dari Dubin. Tahap konseptualisasi dibentuk melalui kombinasi wawancara mendalam, observasi, pengalaman tertulis para abli, dan publikasi penelitian. Kerangka kerja konseptual yang berpotensi meningkatkan kinerja; sebuah organisasi dengan demikian harus memperhatikan bagaimana menyatukan inovasi layanan, kemampuan manajemen pengetahuan, dan pendorong sumber daya manusia dalam model seperti itu dan inilah yang diusulkan di sini. Temuan ini memberikan wawasan berharga tentang peran non-keuangan dan pentingnya variabel organisasi manajemen dalam meningkatkan kinerja organisasi, yang dapat membantu mereka dalam (menyelaraskan) praktik organisasi manajemen mereka.
\end{abstract}

Kata Kunci: kinerja organisasi, perbankan syariah, pengembangan model

\section{How to Cite:}

Pertiwi, R. R., Tjakraatmadja, J.H., Febriansyah, H. (2020). Indonesian Islamic Banking Performance: A Conceptual Framework. Etikonomi: Jurnal Ekonomi, 19(2), 185 - 202. https://doi.org/10.15408/etk.v19i2.16270. 


\section{Introduction}

Organizations are categorized as successful if they can achieve their goals and objectives (Venkatraman \& Ramanujam, 1986) by efficiently and effectively capitalizing on their resources (Daft, 2015). The process of successfully performing a function term as performance. Improving performance is crucial for any organization for some reason. Only through performances are organizations able to grow and progress (Corina et al., 2011); performance can steer organizations toward their strategic and operational goals (Popova \& Sharpanskykh, 2010), and performance helps organizations successfully achieving their vision and mission (Akeem \& Edwin, 2016). Therefore, recognizing the determinants of organizational performance is essential, specifically in the disruptive era's current context.

Previous research has uncovered variables that influence organizational performance, including leadership competency (Almatrooshi et al., 2016), employee performance (Mastrangelo et al., 2014), innovation, inter-organizational systems, and quality (Mafini, 2015), operational efficiencies, mergers, acquisitions, levels of diversification, organizational structures, top management, team composition, and style (Mankins \& Steele, 2005), human capital efficiency (Azlina et al., 2017), and organizational culture (Hogan \& Coote, 2014). Although those studies conducted in various industrial contexts, it can be concluded that organizational performance is a multi-dimensional model that is influenced by a wide variety of internal and external variables. The question is whether these models can apply to all industrial contexts.

This paper uses the Indonesian Islamic Banking (IIB) industry as the context because it is interesting to analyze the three challenges IIB faces. The first challenge is that IIB applies the values of religion in banking, so they are still looking for an identity. However, if in 27 years it has not been established enough, it may be necessary to look for a lack of organizational performan ce. Second, in its search for identity, IIB was confronted with conventional banks that were already established and controlled the market. This condition is certainly a challenge because the market is already familiar with IIB's competitors' products, services, and conventional banking systems. Third, today's banking world faces the challenges of the disruptive era; the financial industry is the third industry to be disrupted by advances in financial technology and market changes. This condition is undoubtedly a challenge for both IIB and conventional banks to adapt to moving forward.

This paper aims to create a model based on internal dimensions that will allow the evaluation of IIB performance as a case study. There are in short supply of studies on organizational performance models' internal management variables, especially in the banking industry. The research questions that arise are: First, what are the main variables that play a significant role in effectively boosting IIB performance? Second, what integrated organizational performance model provides a framework to support and guide the development of IIB's performance? It expects that this paper can uncover insights into organizational performance in organizations that have specific values, late-mover organizations that enter the established market, and organizations that have faced disruption, such as IIB.

This paper is novel because it creates an integrated organizational performance model that can boost organizational performance in Indonesian Islamic banking. This model's 
main advantage is providing valuable insights for organizations into the role of nonfinancial variables and the importance of organizational management variables in improving organizational performance. The results also captured the main variables that play a significant role in effectively boosting IIB performance using a conceptualization phase adapted from Dubin's theory-building method. The findings could help practitioners and academics realign management practices, formulating strategies for IIB, and providing future research needs.

This conceptual paper organizes as follows; section 1 introduces the theoretical and practical problems. The first part describes the need to develop an organizational performance model, and the second describes the particular problems in IIB's performance. Section 2 explains the methods and tools used to develop the model. Section 3 discusses applying the modeling methodology to Indonesia and describes how it creates for this particular case using Dubin's process. Section 4 presents the output of the analysis process: an integrated IIB performance model. Section 5 wraps up the entire discussion in this paper, identifies the practical implications, and makes recommendations for further research.

\section{Methods}

The output expected from this qualitative paper is an integrated conceptual model; consequently, conceptual development needs. The conceptual development output is a clear conceptual framework, including a model or metaphor integrated from previous research knowledge and practitioners' experience with similar issues or problems (Lynham in Swanson \& Chermack, 2013). A model is a visual illustration of the proposed explanation or a set of linked concepts that explains a domain of human activity. Model developments in this paper will use the conceptualization phase adapted from Dubin's theory-building method. Dubin called the results of conceptual development a "theoretical model," as depicted in Figure 1.

Figure 1. Conceptualize Phase

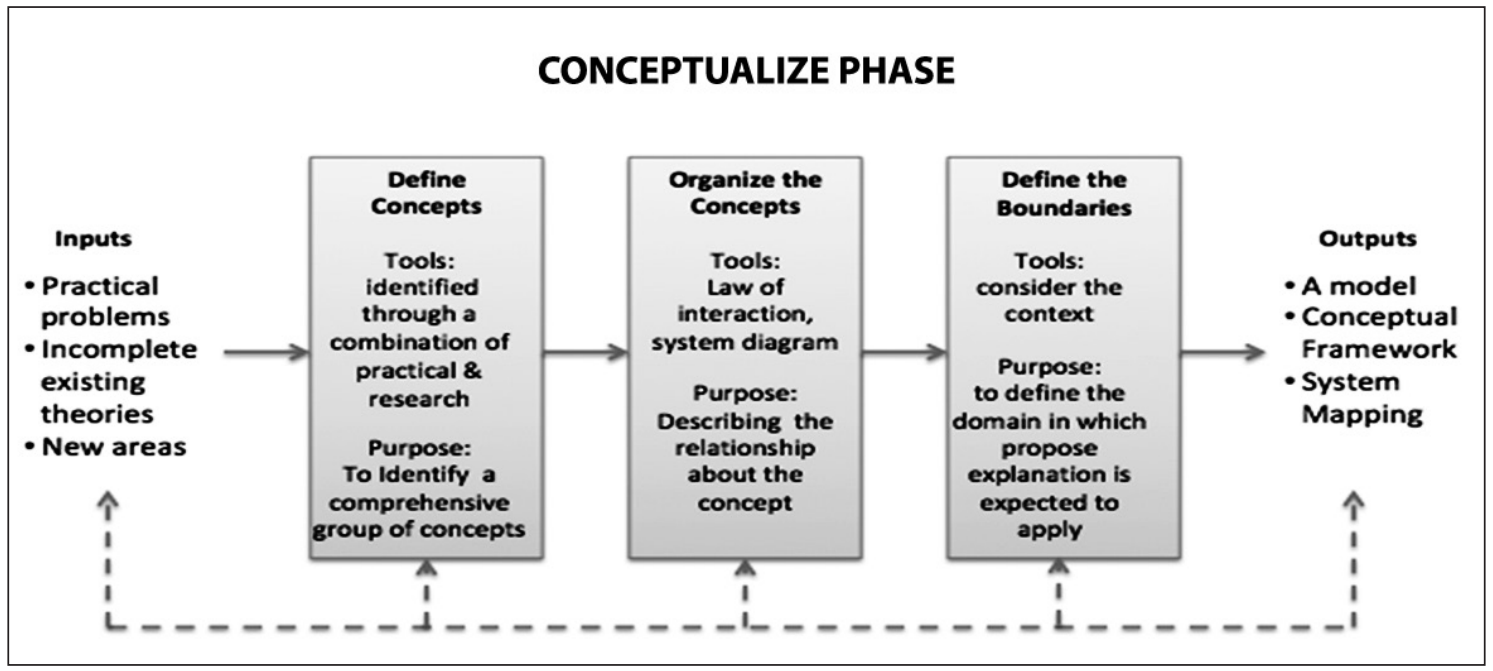

Sources: adapted with adjustment from Durbin (1978) in Swanson \& Chermack (2013) 
The model development process in this paper is as follows. First, inputs that contain incomplete existing theories, state-of-the-art and practical problems, or research gaps are introduced in Section 1 and are discussed more deeply in Section 3. This research's input is the need to develop an integrated IIB model as a theoretical framework and a practical guide to improve IIB performance. This condition indicates the need for conceptual development.

The next step is to define the concepts involved in the theory-building effort. In this step, we conduct in-depth interviews with Islamic banking managers from three banks, collect observational data, and analyze secondary data about the variables that influence IIB's performance. We propose three variables that influence IIB performance, which defines in Section 3. The third step is to organize the concepts by identifying and describing the relationships between them. In this step, we conduct a literature review to describe the relationships between the variables. This step explains in Section 3.

The fourth step is defining the boundaries that locate the theory in the social world and bind it to a particular context. In this phase, the researchers conducted interviews with IIB stakeholders to bring the Islamic banking conceptual model into the Indonesian context. The internal IIB stakeholders include two directors, three managers, and three employees, and the external stakeholders include six customers, two competitors, and three persons from society. This process completes by identifying outputs that postulate an integrated IIB performance model as the final result. These two steps are explained in Section 3.

\section{Result and Discussion}

\section{The Application of the Modeling Methodology to Indonesian Islamic Banking Inputs of the Conceptualization Phase}

Our introduction to the practical problem first describes Islamic banking more generally and then Islamic banking in Indonesia. The first context is Islamic banking, in which there are some fundamental differences in philosophy, system, rules, and regulations from conventional banking. Islamic banking consists of practices based on Islamic laws (sharia). Interest entirely prohibit in Islamic banking. It is asset-based financing in which the trade of elements prohibited by Islam is not allowed. Meanwhile, conventional banking is profit-oriented, and its purpose is to make money through interest.

The second point relates to Islamic banking in Indonesia. Islamic (i.e., sharia) banking in Indonesia began in 1992 with the establishment of Bank of Muamalat Indonesia (BMI) and was welcomed enthusiastically by Islamic communities. In Indonesia, where most people are Muslim, Islamic banking is auspicious because of its vast potential market. In 2017, the population of Indonesia was 229.000.000 people (Central Bureau of Statistics, 2019). About $87.2 \%$ are Muslim, constituting $12.6 \%$ of the global Muslim population (Lipka \& Hackett, 2017). Thus, Indonesia has the largest Muslim population in the world.

Twenty-seven years after its establishment, IIB has shown fast growth in units, branches, employees, and total assets, as seen in Table 1. IIB has increased from one to 
14 units, while IIB increased from eight to 22. The number of IIB offices has increased almost ten-fold (from 299 units to 2301 units) and had spread to all 34 provinces in Indonesia, with one branch located abroad. The number of employees has reached 54,840. Total assets had increased from 5.8 billion Rupiah in 2003 to 524.56 billion Rupiah in December 2019.

Table 1. Indonesian Islamic banking development from 2012 to 2019

\begin{tabular}{lcccccccc}
\hline \multicolumn{1}{c}{ Banking Indicators } & $\mathbf{2 0 1 2}$ & $\mathbf{2 0 1 3}$ & $\mathbf{2 0 1 4}$ & $\mathbf{2 0 1 5}$ & $\mathbf{2 0 1 6}$ & $\mathbf{2 0 1 7}$ & $\mathbf{2 0 1 8}$ & $\mathbf{2 0 1 9}$ \\
\hline Islamic banks (unit) & 11 & 11 & 12 & 12 & 13 & 13 & 14 & 14 \\
Islamic banking unit (unit) & 24 & 23 & 22 & 22 & 21 & 21 & 20 & 20 \\
Total number of offices (unit) & 2271 & 2588 & 2483 & 2301 & 2.201 & 2.169 & 2.229 & 2.301 \\
Number of employee (person) & 27.219 & 38.228 & 45.818 & 55.816 & 55.597 & 55.746 & 54.471 & 54.840 \\
Total asset (Billion IDR) & 195.0 & 242.3 & 272.3 & 296.3 & 356.5 & 424.18 & 477.32 & 524.56 \\
Market-share (\%) & 4.60 & 4.80 & 4.86 & 4.61 & 5.29 & 5.74 & 6.03 & 6.12 \\
\hline
\end{tabular}

However, this data shows that IIB shares are under their targets. Islamic banking's market share (based on total assets) in 2019 was $6.12 \%$ of the total share. The Grand Strategy of Islamic Banking Market Development from OJK targeted a 5\% market share in the first five years, a $10 \%$ market share in the first ten years, and a $15 \%$ market share in the first 15 years. The market share of Islamic banking in Indonesia did not exceed 5\% for more than 20 years (1992-2015), known as the 'five percent trap phenomenon'; although, it finally surpassed 5\% in 2016 (Otoritas Jasa Keuangan, 2018).

Table 2. Market Potential vs Market Share Of Top ten Global Islamic banking

\begin{tabular}{clcccccc}
\hline \multirow{2}{*}{ Ranks } & \multicolumn{4}{c}{ Market Potential } & \multicolumn{3}{c}{ Market Share } \\
\cline { 2 - 8 } & \multicolumn{1}{c}{ Country } & $\begin{array}{c}\text { Muslim } \\
\text { Population }\end{array}$ & $\begin{array}{c}\text { Country } \\
\text { Percentage }\end{array}$ & $\begin{array}{c}\text { Global } \\
\text { Percentage }\end{array}$ & Country & $\begin{array}{c}\text { Share of } \\
\text { Assets }\end{array}$ & Percentage \\
\hline 1 & Indonesia & $229,000,000$ & $87.2 \%$ & $12.60 \%$ & Malaysia & $\$ 205.20$ & $22.70 \%$ \\
2 & Bangladesh & $153,700,000$ & $90.4 \%$ & $8.95 \%$ & Saudi Arab & $\$ 168.80$ & $18.67 \%$ \\
3 & Iran & $82,500,000$ & $99.4 \%$ & $6.50 \%$ & UEA & $\$ 154.90$ & $17.14 \%$ \\
4 & Saudi Arabia & $33,535,000$ & $98.2 \%$ & $2.22 \%$ & Qatar & $\$ 95.70$ & $10.59 \%$ \\
5 & Malaysia & $16,318,355$ & $61.3 \%$ & $1.49 \%$ & Kuwait & $\$ 87.20$ & $9.65 \%$ \\
6 & UEA & $\mathbf{7 , 2 5 1 , 6 2 7}$ & $76 \%$ & $0.28 \%$ & Bahrain & $\$ 52.40$ & $5.80 \%$ \\
7 & Kuwait & $\mathbf{2 , 1 7 5 , 6 8 4}$ & $\mathbf{7 4 . 6 \%}$ & $0.23 \%$ & Iran & $\$ 35.90$ & $3.97 \%$ \\
8 & Qatar & $\mathbf{1 , 5 6 6 , 7 8 6}$ & $\mathbf{7 7 , 5 \%}$ & $0.10 \%$ & Bangladesh & $\$ 28.90$ & $3.20 \%$ \\
9 & Bahrain & $\mathbf{1 , 0 6 3 , 2 3 9}$ & $\mathbf{7 3 . 7 \%}$ & $0.08 \%$ & Indonesia & $\$ 21.40$ & $2.37 \%$ \\
10 & Others & $\mathbf{1 , 1 5 0 , 2 8 6 , 8 4 7}$ & - & $70.74 \%$ & Others & $\$ 53.50$ & $5.92 \%$ \\
\hline
\end{tabular}

Source: Lipka \& Hackett (2017) and Weng (2019) 
Globally, nine countries contribute $94.08 \%$ of the total share of Islamic, as seen in table 2. The right column presents market share ranking based on total assets (Weng, 2019), and the left column is the ranking of market potential based on the respective Muslim population (Lipka \& Hackett, 2017). Indonesia, with the largest Muslim population in the world, is ranked first in market potential. However, if we see the assets or market share, IIB only contributes $2.37 \%$, meaning IIB ranks ninth in market share.

From the description above, it is clear that there is a problem in IIB performance, as summarized in Figure 2. There is a gap between IIB potential and performance. Organizations at its maturity level should have already achieved their objectives and have healthy performance. However, in reality, there are still many challenges to overcome. The ability to recognize the most influential variables and to properly manage challenges has indeed become the key to improving organizational performance. That is why this paper proposes an integrated model that can improve IIB performance. Many studies discuss macro- and micro-factors that influence organizational performance. This paper will focus on micro-factors.

Figure 2. Indonesian Islamic Banking Characteristics

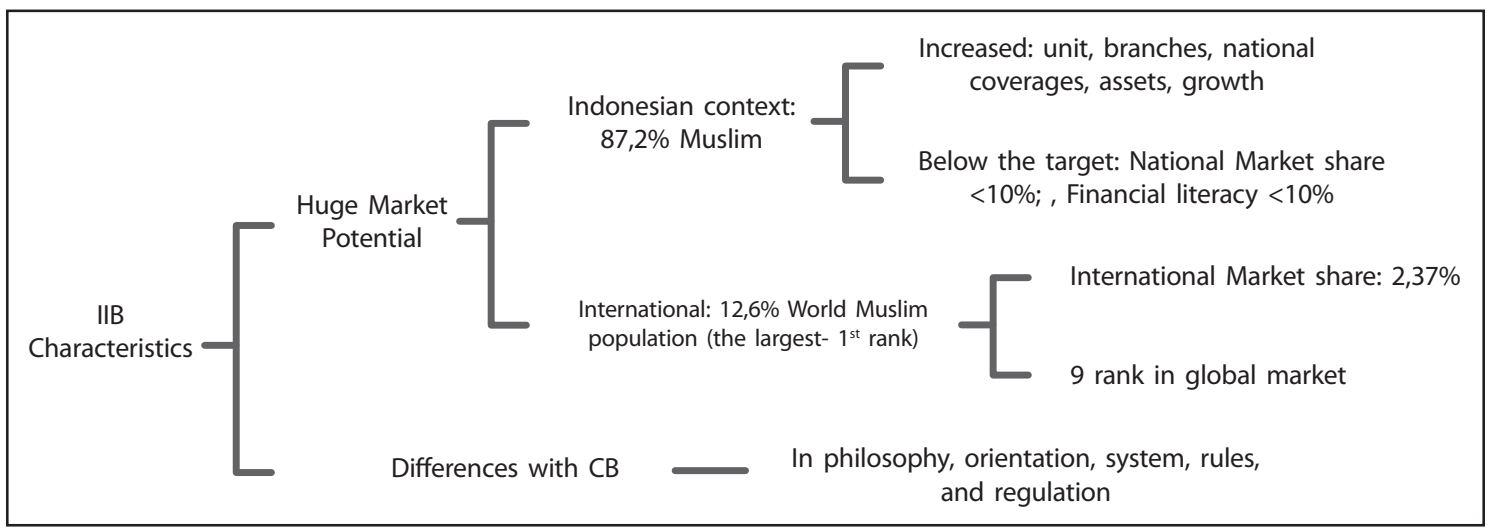

Sources: abstracted from many resources

\section{Incomplete Existing Theory}

For the last three decades, organizational performance has become central to the organization, business, and management research because it is considered a means of detecting organizational health and success. Along with increasing research on organizational performance, many research studies have emerged which propose organizational performance models, including the organizational lag model (Damanpour \& Evan, 1984), the innovationdriven organizational performance model (Baker \& Sinkula, 1999), organizational culture and performance model (Marcoulides \& Heck, 1993), the modeling organizational performance indicators (Popova \& Sharpanskykh, 2010), determinants of organizational performance (Corina et al., 2011), an evolutionary model of organizational performance (Barnett et al., 1994), and the Schein model test (Hogan \& Coote, 2014). The models are partly conceptual; some have tested, but none examines the context of organizations that are late-movers and that disruptive face era. This paper will fill this research gap. 
The increasing research on the organizational performance model has led to the formulation of theories about variables within organizations that can make a difference in performance. Previous research found effects of variables in increasing organisational performance, such as innovation (Damanpour \& Evan, 1984; Baker \& Sinkula, 1999; Corina et al., 2011; Hogan \& Coote, 2014); organizational culture (Hogan \& Coote, 2014); human capital (Gelade \& Ivery, 2003); and knowledge management (Darroch, 2005).

Macroeconomic factors and financial variables influence most studies on IB performance; only a few have examined the effect of management variables on Islamic banking performance. The following management variables that affect Islamic banks' performance have examined in the literature: human resource management practices (Masum et al., 2016); sharia supervision and corporate governance (Mollah \& Zaman, 2015), intellectual capital (Nawaz \& Haniffa, 2017); corporate social responsibility (Faliza, 2016).

There is a shifting research focus on Islamic banking performance initially following conventional bank performance by focusing on financial performance aspects (Rafiq, 2016; Rodoni et al., 2017; Rosly \& Abu Bakar, 2003; ) and Islamic banking efficiency (Al Arif et al., 2020; Shahid et al., 2010; Yudistira, 2004). The research then developed into linking organizational performance with sharia, starting from the promotion of sharia compliance and Islamic ethics (Hameed et al., 2004; Nawaz \& Haniffa, 2017). Some scholars then made measurements by the objectives of establishing a sharia bank using the maqashid sharia framework. The maqashid sharia theory is twofold, comprising AlGhazali's theory as a pioneering classical and integrative interpretation (Ascarya et al., 2017; Asutay \& Harningtyas, 2015; Bedoui \& Mansour, 2015) and Abu Zuhairah's theory as a contemporary interpretation that more often implemented in the organizational context (Mohammed et al., 2008; Rusydiana \& Parisi, 2016; Antonio et al., 2012).

The framework using Abu Zuhairah's maqashid theory has become widely used. Several studies have measured the performance of Indonesian Islamic banks using this measurement tool (Ascarya et al., 2017; Hosen et al., 2019; Mifrahi \& Fakhrunnas, 2018; Nugraha et al., 2020; Permana et al., 2017; Rusydiana \& Sanrego, 2018; Soleh, 2016; Antonio et al., 2012). There are three dimensions of this measurement: educating people, establishing justice between stakeholders, and promoting welfare. The results show that IIB has not yet paid attention to human capital (index point: 0.18 of $30 \%$ ). This condition will affect the quality of internal human capital, organizational knowledge. It will not provide a good atmosphere for innovation and influence customers' Islamic banking literacy in the long run. The second dimension is establishing justice (index point: $6.75 \%$ of $41 \%$ ). This dimension means the products developed in Islamic Banking do not yet reflect sharia. Its flagship product still imitates conventional banks. 
Figure 3. Incomplete Existing Theory of Islamic Banks Performance

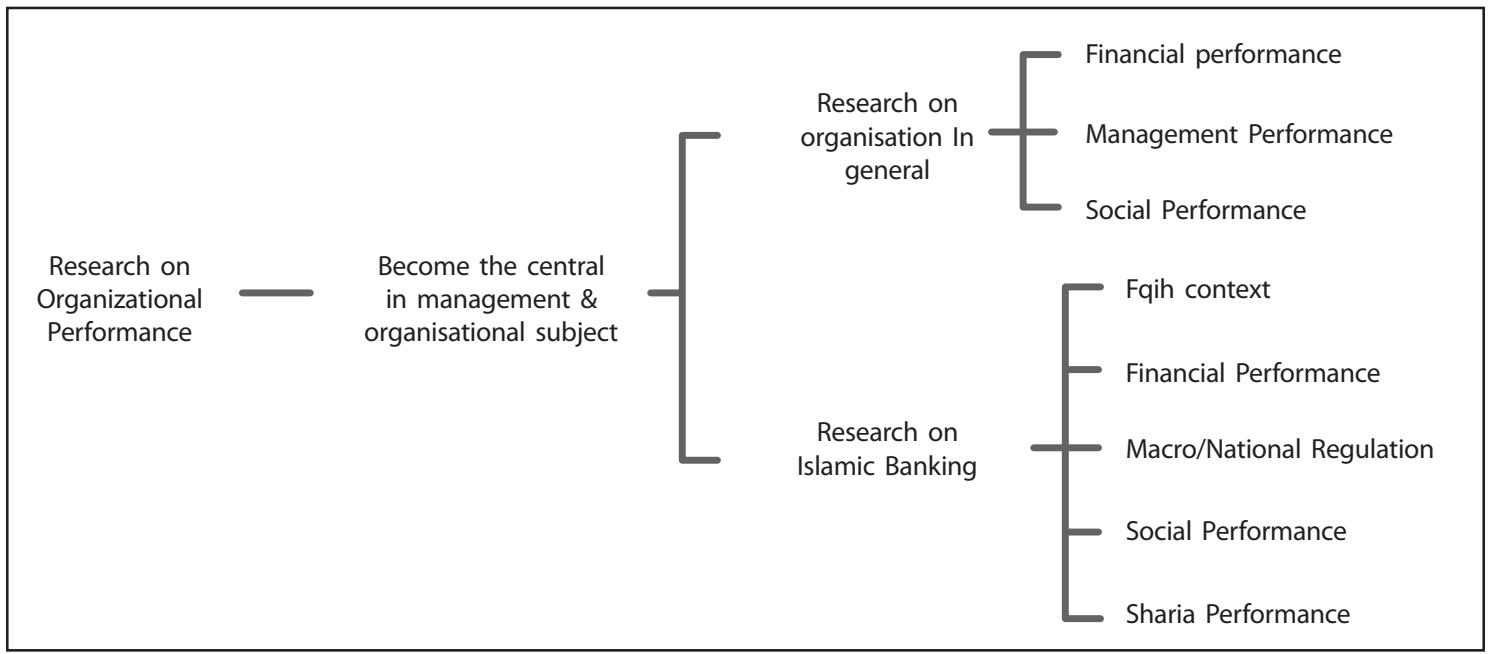

Sources: abstracted from many resources

From the description above, research mapping on organizational performance summarize in Figure 3. There is research scarce on Islamic Banking performance in the context management. Based on the presentation of the practical problems and incomplete existing theory summarized in Figures 2 and 3 in the section input conceptualization phase above, this paper found the need to develop an integrated IIB model as a theoretical framework and practical guide improving IIB performance. This condition indicates the need for conceptual development that starts with defining the concept.

\section{Define the concepts}

The concept defined here is a variable that affects organizational performance. Based on the study of sharia banking practitioners (Kuwait Finance House KSCP and Subsidiaries, 2013). Indonesia still occupies the third cluster in Islamic banking with regard to innovative products and services. The fourth cluster, which is the highest cluster, includes Malaysia, United Arab Emirates, and Bahrain. The fourth cluster is the most innovative and varied in product development. Indonesia, Brunei, North Africa, Turkey, and Qatar are in the third cluster. Thus, they still fall short when compared to the fourth cluster. The facts show that the innovation in sharia banking products in Indonesia is still lacking.

It cannot be denied that there is a strong correlation between product, service innovation, and market attention in Islamic banking. It can be said that the more innovative Islamic banking's products and services are, the faster the market will grow. From these phenomena, this paper proposes that the first variable that influences organizational performance is service innovation. Service innovation refers to a new service experience or service solution that involves at least one of the following four dimensions: a new service concept, a new customer interaction, a new value system, and a new delivery system and technology (den Hertog et al., 2010). 
The second variable that is predicted to influence organizational performance is human capital. Qualified human capital is scarce in Islamic banking. Human capital in this context describes people who are committed, qualified, and competent in the sharia system so they can participate and contribute to the development of Islamic banking (Faliza, 2016). There is ample qualified human capital in banking, but they typically prefer conventional banking because they have better remuneration and brand images. Roughly $85 \%$ of the 300,000 human resources working in the Islamic banking industry currently lack sufficient knowledge of sharia (Antonio et al., 2012). Previous research has studied human capital management drivers and organizational performance (Bassi \& Mcmurrer, 2006; Jamal \& Saif, 2011); human capital drivers in Islamic banking (Muafi et al., 2017), and human capital as a driver for innovation (Mariz-Perez et al., 2012).

The next variable is knowledge management $(\mathrm{KM})$. $\mathrm{KM}$ is the capability to create action from knowledge. It can be initiated from multiple sources and experiences (Ho, 2008). Different from conventional banking, the name 'Islamic' has profound consequences on an organization's vision, mission, culture, and practices that require specific knowledge; therefore, it can be assumed that KM plays a critical role in that industry. Based on previous research, KM can support innovation and performance (Darroch, 2005)743 surveys were mailed out and 443 were returned and usable (27.8 percent response rate. Research that discusses KM in IB varies in focus, including research from Cader et.al (2013), which states that IB are more involved in KM than conventional banks in the UAE. Nurdin and Yusuf (2020) examine the KM lifecycle model in IB, and Abuazoum et al. (2013) studies knowledge sharing in Islamic banking. However, none of these studies were completed in the context of Indonesia or the development of a model to support organizational performance.

\section{Organizing the Concepts}

Once the concepts are identified, they must be organised. This means identifying and describing the relationships among them. This leads to the development of propositions that should be tested. The first proposition is that service innovation will improve organizational performance. Previous literature has stated that service innovation influences organizational performance by decreasing operational costs (Panesar \& Markeset, 2008); increasing sales revenues (Kubeczko et al., 2006; Mansury \& Love, 2008), and improving organizational profitability (Matear et al., 2004). Previous research conducted across countries found that innovation influences organizational performance (Baldwin \& Johnson, 1996; Dwyer \& Mellor, 1993). Organizational performance in those studies was determine using various measurements such as size, growth rate, return on investment, profitability, and market share. This shows that innovation influences different aspects of organizational performance. Other researchers found that the type and absorption time of innovation have an impact on business performance. Yamin et al. (1997) found that process innovation more strongly predicts organizational performance than product innovation does.

The second proposition is that human capital drivers will improve organizational performance. Human capital is the most valuable organizational asset; it is an invisible asset 
that boosts organizational performance. Some empirical studies support this proposition, such as a study that found that human resource flexibility is positively correlated with return on sales, operating profit per employee, and sales per employee (Bhattacharya et al., 2005). Another study proved the positive and significant relationship between human capital efficiency and organizational performance (Azlina et al., 2017; Jamal \& Saif, 2011); Other research has shown that human capital value can improve companies' market values (Hajiha \& Hansanloo, 2009).

The third proposition is that KM capability will increase organizational performance. There are various research studies about the relationship between these variables, focusing on the link between human capital management and KM to increase organizational performance (Afiouni, 2007), and the correlation between KM capability, the processes, and performance (Lin, 2013). The three components of KM capability that influence organizational performance are the organization's capacity to create new knowledge, build on it, and capture a high proportion of subsequent spin-offs (Bogner \& Bansal, 2007).

The fourth proposition is that service innovation acts as the mediator between human capital drivers and organizational performance. Previous literature, theories, and empirical evidence explain the relationship between human capital and organizational performance but scarcely explain the value of innovation as a mediator (Camisón \& Villar-López, 2014). Different research contexts propose the correlation between human capital and desired performance and outcomes, such as SME development, job creation, innovation, and economic development (Frese et al., 2002; Cao et al., 2016; Sarwar et al., 2016). Further Sarwar et al. (2016) found that innovation mediates the relationship between human capital and organizational performance. Human capital creates and stores knowledge (Smith et al., 2005), and has the capacity to absorb, organise, and create knowledge as a source of innovation. From this proposition, we can conclude that human capital has a pivotal role in creating service innovations. Meanwhile, the innovation of products and services is a significant organizational performance determinant (Damanpour, 1991). The introduction of new services will increase the market share rate, which in the long run, will improve organizational performance.

The fifth proposition is that service innovation acts as a mediator between $\mathrm{KM}$ capability and organizational performance. Jyoti et al. (2011) stated that the impact of KM on organizational performance mainly relates to the ability of organizations to innovate by improving both products and processes. Previous research asserted that that effective KM is mediated by innovation to increase organizational performance (Darroch, 2003; Gold et al., 2001; Han et al., 1998). KM then could be viewed as creating organizational performance through service innovation. Of these variables, this paper concentrates on the role of service innovation, leaving a discussion of the specific meaning for a future paper. Service innovation was selected as the first object of this model due to its important mediating role.

When we consider our model, we must define its scope and boundaries, as indicated in Figure 3, to define the limits and conditions that apply to the proposed model. In this case, the boundaries are Islamic banking and the Indonesian context. The first boundary is Islamic banking because (1) Islamic banking's vision is specific not only for profit, like other 
organizations, but also for wealth; (2) it is specific vision has implications for its operational, management, human capital, and organizational performance; (3) its differences from conventional banking are already well established; and (4) its products should follow not only customer needs but also sharia, so they require more innovation than other.

This paper explores Islamic banking in the Indonesian context, taking the following considerations into account: (1) it is still low in terms of service innovation, (2) it has problems with human capital, and (3) it needs to improve its KM capabilities. This paper's domain is consequently a model of organizational performance concerning KM capability, human capital drivers, and service innovation using the conceptualization phase method in IIB.

\section{Outputs of the Conceptualize Phase}

Based on the conceptual phase above, this study proposes a model that illustrates the dynamic relationship between IIB performance and the three variables that are suspected to be the causes. The model and detailed explanation are discussed in the next section to describe the final result that will integrate all the paper processes.

The final result from the conceptualization model is an integrated model of IIB performance, as presented in Figure 4. In general, the model illustrates the relationship between the six propositions explained in the sections above, but this model adds a more detailed explanation about the dimensions of each variable explicitly.

Figure 4. An integrated model of Indonesian Islamic Banking Performance

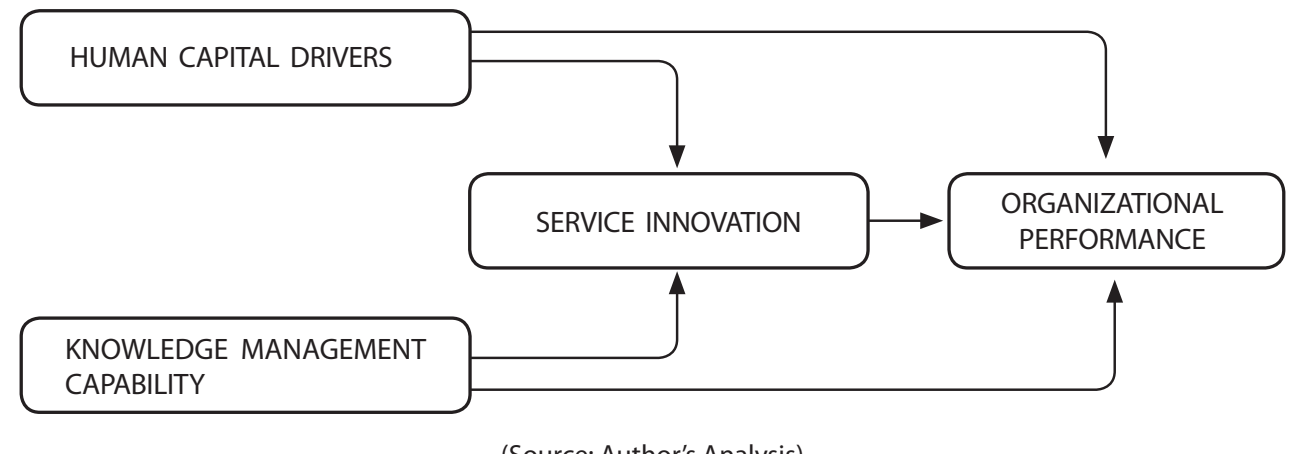

(Source: Author's Analysis)

There are six propositions (P1-P6) in this model divided into three primary relationships below:

Organizational performance is influenced directly by service innovation (P1), human capital drivers (P2), and KM capability (P3).

Islamic banks are industries whose products are services, so innovations in the service sector will improve organizational performance. It cannot deny that there is a strong relationship between product/service innovation and market attention, which will influence performance. To develop service innovations, an organization should consider developing a new value system, a new service concept, a new customer interaction, and a new delivery system and technology. 
In Islamic banks, there are issues embedded in hiring non-Muslim staff and contractors who lack knowledge of sharia. This condition would present a problem should they run the bank's operations. To overcome the issue and develop a more profound comprehension of its staff's needs and requests requires bolstering the learning sharing. Learning and improving knowledge about sharia in operation should be enabled using KM. If every person in the organization knows these needs, personal knowledge will become organizational knowledge and boost innovation and organizational performance.

Bassi \& Mcmurrer (2006) developed a human capital driver methodology to identify and manage human capital management process variations that affect organizational performance. With a tool to measure human capital management, an organization can start assessing how well they manage and develop their people. The human capital department must undertake the strategic responsibility of making sure effective human capital management becomes a priority in its culture. Daily coaching, mentoring, and monitoring of human capital activities in the organization can improve organizational performance in the long run.

Service innovation is a mediating variable between human capital drivers (P4), KM capability (P5), and IIB performance, which means service innovation, is a crucial variable that can boost organizational performance.

The two variables above can improve service innovation and, eventually, organizational performance. Innovation should be the central aspect to develop. The development should do at every level, in every division, and among every person in the organization.

Human capital drivers will improve KM capability (P6). Optimizing human capital driver dimensions, including employee engagement, leadership practices, knowledge accessibility, workforce optimization, and learning capacity, can improve KM capabilities.

\section{Conclusion}

This study proposes a model to improve IIB performance; organizations should pay attention to the close integration of service innovation, KM capability, and human capital drivers. Since Islamic banks have specific characteristics and visions, service innovation is the key to developing competitive products and services to fulfil customer needs, achieve organizational visions, and satisfy stakeholders. These conditions can boost organizational performance, so innovation must become the central variable to strengthen. Maximizing KM capability and human capital drivers can increase Service innovation.

There are several practical implications. Firstly, for Islamic banking should develop a system in which every person at every level in the organization can be an innovator since service innovation as a moderating variable is a key to boosting organizational performance. Secondly, attention toward management indeed, the impact is not seen directly on organizational performance, such as financial ratios, but it will give a continuous improvement in an organization's overall performance in the long run. In this case, Islamic banking should improve human capital drivers and KM within the organization. Thirdly, as a regulator, the Financial Services Authority needs to campaign not only for regulations and hard skill 
competency but also for soft skill competency for organizations or people involved in Islamic banking activities.

The proposed model creates from theoretical studies; an empirical study needs to evaluate the proposed model's practical applications. Further studies should emphasize the validation of the proposed model in terms of its significance and practicality. Testing the proposed model in an empirical situation (such as Islamic banks, conventional banks, or organizations) will provide useful information for professionals in implementing the proposed model. This paper has not yet demonstrated the overall management variables that affect organizational performance. Further research should determine other management factors that affect organizational performance in different contexts. An alternative area for future research is the question of how to develop innovative services, KM capabilities, and human capital drivers in Islamic banks, precisely and in organizations in general.

\section{References}

Abuazoum, A. A. A., Azizan, N., \& Ahmad, N. (2013). Knowledge Sharing for the Islamic Banking Sector in Malaysia. International Journal of Computer and Communication Engineering, 2(3), 368-371. https://doi.org/10.7763/ijcce.2013.v2.206

Afiouni, F. (2007). Human Resource Management and Knowledge Management: A Road Map Toward Improving Organizational Performance. Journal of American Academy of Business, 11(2), 124-130.

Akeem, A., \& Edwin, M. (2016). Vision and Mission in Organization : Myth or Heuristic Device? The International Journal of Business and Management, 4(3), 127-134.

Al Arif, M. N. R., Mufraini, M. A., \& Prabowo, M. A. (2020). Market Structure, SpinOff, and Efficiency: Evidence from Indonesian Islamic Banking Industry. Emerging Markets Finance and Trade, 56(2), 329-337. https://doi.org/10.1080/154049 6X.2018.1553162

Almatrooshi, B., Singh, S. K., \& Farouk, S. (2016). Determinants of Organizational Performance:aProposedFramework. InternationalJournalofProductivityandPerformance Management, 65(6), 844-859. https://doi.org/10.1108/IJPPM-02-2016-0038.

Antonio, M. S., Sanrego, Y. D., \& Taufiq, M. (2012). An Analysis of Islamic Banking Performance: Maqashid Index Implementation in Indonesia and Jordania. Journal of Islamic Finance, 1(1), 12-29.

Ascarya, Rahmawati, S., \& Sukmana, R. (2017). Measuring The Islamicity of Islamic Bank in Indonesia and other Countries Based on Shari'ah Objectives. 11th Islamic Conference on Islamic Economics and Finance, 1-31.

Asutay, M., \& Harningtyas, A. F. (2015). Developing Maqasid al-Shari'ah Index to Evaluate Social Performance of Islamic Banks: A Conceptual and Empirical Attempt. International Journal of Islamic Economics and Finance Studies, 1(1), 5-64.

Azlina, R., Ruhaya, A., \& Amrizah, K. (2017). Human Capital Efficiency and Firm Performance: an Empirical Study on. SHS Web of Conference 36, 00026. 
Baker, W., \& Sinkula, J. (1999). Learning Orientation, Market Orientation, and Innovation: Integrating and Extending Models of Organizational Performance. Journal of MarketFocused Management, 4(4), 295-308. https://doi.org/10.1023/A:1009830402395

Baldwin, J. R., \& Johnson, J. (1996). Business Strategies in More- and Less-Innovative Firms in Canada. Research Policy, 25(5), 785-804. https://doi.org/10.1016/00487333(95)00875-6

Barnett, W. P., Greve, H. R., \& Park, D. Y. (1994). An Evolutionary Model of Organizational Performance. Strategic Management Journal, 15(S1), 11-28. https://doi.org/10.1002/ smj.4250150903.

Bassi, B. L., \& Mcmurrer, D. (2006). Human Capital and Organizational Performance: Next Generation Metrics as a Catalyst for Change. White Paper, McBassi \& Company.

Bedoui, H. E., \& Mansour, W. (2015). Performance and Maqasid al-Shari'ah's PentagonShaped Ethical Measurement. Science and Engineering Ethics, 21(3), 555-576. https:// doi.org/10.1007/s11948-014-9561-9

Bhattacharya, M., Gibson, D. E., \& Doty, D. H. (2005). The Effects of Flexibility in Employee Skills, Employee Behaviors, and Human Resource Practices on Firm Performance. Journal of Management, 31(4), 622-640. https://doi.org/10.1177/0149206304272347

Bogner, W. C., \& Bansal, P. (2007). Knowledge Management as the Basis of Sustained High Performance. Journal of Management Studies, 44(1), 165-188. https://doi.org/10.1111/ j.1467-6486.2007.00667.x

Cader, Y., O’Neill, K. K., Blooshi, A. A., Shouq, A. A. B. Al, Fadaaq, B. H. M., \& Ali, F. G. (2013). Knowledge Management in Islamic and Conventional Banks in the United Arab Emirates. Management Research Review, 36(4), 388-399. https://doi. org/10.1108/01409171311314996

Camisón, C., \& Villar-López, A. (2014). Organizational Innovation as an Enabler of Technological Innovation Capabilities and Firm Performance. Journal of Business Research, 67(1), 2891-2902. https://doi.org/10.1016/j.jbusres.2012.06.004.

Cao, Q., Criscuolo, P., \& Autio, E. (2016). SME Internasionalisation and Its Impact on Firm Performance. In Tüselmann, H., Buzdugan, S., Cao, Q., Freund, D., \& Golesorkhi, S. (eds). Impact of International Business. London: Plagrave Macmillan.

Central Bureau of Statistics. (2019). Statistik Indonesia 2019. Jakarta: Central Bureau of Statistics.

Corina, G., Liviu, I., \& Roxana, S. (2011). Determinants of Organizational Performance : the Case of Romania. Management \& Marketing Challenges for the Knowledge Society, 6(2), 285-300.

Daft, R. L. (2015). Organization Theory and Design. New Jersey: South-Western Cengage Learning.

Damanpour, F. (1991). Organizational Innovation: A Meta-Analysis of Effects of Determinants and Moderators. Academy of Management Journal, 34(3), 555-590. https://doi. org/10.2307/256406

Damanpour, F., \& Evan, W. M. (1984). Organizational Innovation and Performance: The Problem of Organizational Lag. Administrative Science Quarterly, 29(3), 392-409. 
Darroch, J. (2003). Developing a Measure of Knowledge Management Behaviors and Practices. Journal of Knowledge Management, 7(5), 41-54. https://doi. org/10.1108/13673270310505377

Darroch, J. (2005). Knowledge Management, Innovation and Firm Performance. Journal of KnowledgeManagement,9(3), 101-115.https://doi.org/10.1108/13673270510602809

den Hertog, P., van der Aa, W., \& de Jong, M. W. (2010). Capabilities for Managing Service Innovation: Towards a Conceptual Framework. Journal of Service Management, 21(4), 490-514. https://doi.org/10.1108/09564231011066123

Dwyer, L., \& Mellor, R. (1993). Product Innovation Strategies and Performance of Australian Firms. Australian Journal of Management, 18(2), 159-180. https://doi. org/10.1177/031289629301800202

Faliza, N. (2016). CSR and Islamic Banking Performance in Aceh: The Role of Innovation as Mediation. Journal of Management and Marketng Review, 1(1), 45-56.

Frese, M., Brantjes, A., \& Hoorn, R. (2002). Psychological Success Factors of Small Scale Business in Namibia: The Roles of Strategy Process, Entrepreneurial Orientation and the Environment. Journal of Developmental Entrepreneurship, 7(3), 259-282.

Gelade, G. A., \& Ivery, M. (2003). The Impact of Human Resource Management and Work Climate. Personnel Psychology, 56(2), 383-404.

Gold, A. H., Malhotra, A., \& Segars, A. H. (2001). Knowledge Management: an Organizational Capabilities Perspective. Journal of Management Information Systems, 18(1), 185-214. https://doi.org/10.1080/07421222.2001.11045669

Hajiha, Z., \& Hansanloo, S. (2009). An Empirical Study of the Relationships among Human Capital Value and Profitability and Market Value: Comparison of KnowledgeBased Industries and Non Knowledge-Based Industries. Asian Journal of Business and Management Sciences, 1(3), 105-114.

Hameed, S., Mohamed, B., Ade, I., Bakhtiar, W., Mohd, A., Bin, N., Nor, M., \& Pramono, S. (2004). Alternative Disclosure and Performance Measures for Islamic Banks. Proceeding of The Second Conference on Administrative Science: Meeting The Challenges of The Globalization Age.

Han, J. K., Kim, N., \& Srivastava, R. K. (1998). Market Orientation and Organizational Performance: is Innovation a Missing Link? Journal of Marketing, 62(4), 30-45. https:// doi.org/10.2307/1252285

Harfiah, L. M., Purwati, A. S., \& Ulfah, P. (2016). The Impact of ROA, BOPO, and FDR to Indonesian Islamic Bank's Mudharabah Deposit Profit Sharing. Etikonomi, 15(1), 19-30. https://doi.org/10.15408/etk.v15i1.3109

Ho, L. A. (2008). What Affects Organizational Performance? the Linking of Learning and Knowledge Management. Industrial Management and Data Systems, 108(9), 12341254. https://doi.org/10.1108/02635570810914919

Hogan, S. J., \& Coote, L. V. (2014). Organizational Culture, Innovation, and Performance: a Test of Schein's Model. Journal of Business Research, 67(8), 1609-1621. https://doi. org/10.1016/j.jbusres.2013.09.007 
Hosen, M. N., Jie, F., Muhari, S., \& Khairman, M. (2019). The Effect of Financial Ratios, Maqasid Sharia Index, and Index of Islamic Social Reporting to Profitability of Islamic Bank in Indonesia. Al-Iqtishad: Jurnal Ilmu Ekonomi Syariah, 11(2), 201-222. https:// doi.org/10.15408/aiq.v11i2.11588.

Jamal, W., \& Saif, M. I. (2011). Impact of Human Capital Management on Organizational Performance. European Journal of Economics Finance, and Administrative Sciences, 34, 55-69.

Jyoti, J., Gupta, P., \& Kotwal, S. (2011). Impact of Knowledge Management Practices on Innovative Capacity. Vision: The Journal of Business Perspective, 15(4), 315-330. https:// doi.org/10.1177/097226291101500402

Kubeczko, K., Rametsteiner, E., \& Weiss, G. (2006). The Role of Sectoral and Regional Innovation Systems in Supporting Innovations in Forestry. Forest Policy and Economics, 8(7), 704-715. https://doi.org/10.1016/j.forpol.2005.06.011

Kuwait Finance House KSCP and Subsidiaries. (2013). 35th Annual Report. In Kuwait Finance House (Vol. 48, Issue 3). https://doi.org/10.1109/jaiee.1929.6535127

Lin, L. (2013). The Impact of Service Innovation on Firm Performance. Service Industries Journal, 33(15-16), 1599-1632. https://doi.org/10.1080/02642069.2011.638712

Lipka, M., \& Hackett, C. (2017). Why Muslims are the World's Fastest-Growing Religious Group. Retrieved from: https://www.pewresearch.org/fact-tank/2017/04/06/whymuslims-are-the-worlds-fastest-growing-religious-group/

Mafini, C. (2015). Performance Through Innovation, Quality And Inter-Organizational Systems. Journal of Applied Business Research, 31(3), 939-952.

Mankins, M. C., \& Steele, R. (2005). Turning Great Strategy into Great Performance. In Harvard Business Review. Retrieved from: https://hbr.org/2005/07/turning-greatstrategy-into-great-performance

Mansury, M. A., \& Love, J. H. (2008). Innovation, Productivity and Growth in US Business Services: a Firm-level Analysis. Technovation, 28(1-2), 52-62. https://doi. org/10.1016/j.technovation.2007.06.002

Marcoulides, G. A., \& Heck, R. H. (1993). Organizational Culture and Performance: Proposing and Testing a Model. Organization Science, 4(2), 209-225. https://doi. org/10.1287/orsc.4.2.209

Mariz-Perez, R. M., Teijeiro-Alvarez, M. M., \& Garcì-Alvarez, M. T. (2012). The Relevance of Human Capital as a Driver for Innovation. Cuadernos de Economia (Spain), 35(98), 68-76. https://doi.org/10.1016/S0210-0266(12)70024-9

Mastrangelo, A., Eddy, E. R., \& Lorenzet, S. J. (2014). The Relationship Between Enduring Leadership and Organizational Performance. Leadership and Organization Development Journal, 35(7), 590-604. https://doi.org/10.1108/LODJ-08-2012-0097

Masum, A. K. M., Azad, M. A. K., \& Beh, L. S. (2016). The Role of Human Resource Management Practices in Bank Performance. Total Quality Management and Business Excellence, 27(3-4), 382-397. https://doi.org/10.1080/14783363.2014.1002762

Matear, S., Gra, B. J., \& Garrett, T. (2004). Market Orientation, Brand Investment, New 
Service Development, Market Position and Performance for Service Organizations. International Journal of Service Industry Management, 15(3), 284-301. https://doi. org/10.1108/09564230410540944

Mifrahi, M. N., \& Fakhrunnas, F. (2018). Islamic Bank Performance Based on Maqasid Based Performance Evaluation Model (MPEM). Jurnal Ekonomi \& Keuangan Islam, 4(2), 93-103. https://doi.org/10.20885/jeki.vol4.iss2.art6

Mohammed, M. O., Razak, D. A., \& Taib, F. M. (2008). The Performance Measures of Islamic Banking Based on the Maqasid Framework. IIUM International Accounting Conference (INTAC IV).

Mollah, S., \& Zaman, M. (2015). Shari'ah Supervision, Corporate Governance and Performance: Conventional vs. Islamic banks. Journal of Banking and Finance, 58, 418-435. https://doi.org/10.1016/j.jbankfin.2015.04.030

Muafi, Suwitho, Purwohandoko, \& Salsabil, I. (2017). Human Capital in Islamic Bank and Its Effect on the Improvement of Healthy Organization and Employee Performance. International Journal for Quality Research, 11(4), 849-868. https://doi.org/10.18421/ IJQR11.04-08.

Nawaz, T., \& Haniffa, R. (2017). Determinants of Financial Performance of Islamic Banks: an Intellectual Capital Perspective. Journal of Islamic Accounting and Business Research, 8(2), 130-142. https://doi.org/10.1108/JIABR-06-2016-0071

Nugraha, E., Nugroho, L., Lindra, C., \& Sukiati, W. (2020). Maqashid Sharia Implementation in Indonesia and Bahrain. Etikonomi, 19(1), 155-168. https://doi.org/10.15408/etk. v19i1.14655

Nurdin, \& Yusuf, K. (2020). Knowledge Management Lifecycle Model in Islamic Banks: The Case of Syariah Banks in Indonesia. International Journal of Knowledge Management Studies, 11(1), 59-80. https://doi.org/10.1504/IJKMS.2020.105073.

Otoritas Jasa Keuangan. (2018). Statistik Perbankan Indonesia 2017. Jakarta: Otoritas Jasa Keuangan.

Panesar, S. S., \& Markeset, T. (2008). Industrial Service Innovation Through Improved Contractual Relationship: a Case Study in Maintenance.JournalofQuality in Maintenance Engineering, 14(3), 290-305. https://doi.org/10.1108/13552510810899481

Permana, I. J., Robiani, B., Marwa, T., \& Azwardi. (2017). An Analysis of Structure, Behavior and Banking Performance of Islamic Banking in Indonesia. Eurasian Journal of Economics and Finance, 5(1), 114-127. https://doi.org/10.15604/ejef.2017.05.01.008

Popova, V., \& Sharpanskykh, A. (2010). Modeling Organizational Performance Indicators. Information Systems, 35(4), 505-527. https://doi.org/10.1016/j.is.2009.12.001

Rafiq, M. R. I. (2016). Determining Bank Performance Using CAMEL Rating: a Comparative Study on Selected Islamic and Conventional Banks in Bangladesh. Asian Business Review, 6(3), 151-160. https://doi.org/10.18034/abr.v6i3.40

Rodoni, A., Salim, M. A., Amalia, E., \& Rakhmadi, R. S. (2017). Comparing Efficiency and Productivity in Islamic Banking: Case Study Indonesia, Malaysia and Pakistan. 
Ruspita Rani Pertiwi. Indonesian Islamic Banking Performance: A Conceptual Framework

Al-Iqtishad: Journal of Islamic Economics, 9(2), 227-242. https://doi.org/10.15408/aiq. v9i2.5153

Rosly, S. A., \& Abu Bakar, M. A. (2003). Performance of Islamic and mainstream banks in Malaysia. International Journal of Social Economics, 30(11-12), 1249-1265. https:// doi.org/10.1108/03068290310500652

Rusydiana, A. S., \& Parisi, S. Al. (2016). The Measurement of Islamic Bank Performance: A Study Using Maqasid Index and Profitability. Global Review of Islamic Economics and Business, 4(1), 1-14.

Rusydiana, A., \& Sanrego, Y. D. (2018). Measuring the Performance of Islamic Banking in Indonesia: an Application of Maslahah-Efficiency Quadrant (MEQ). Journal of Islamic Monetary Economics and Finance, 3, 103-130. https://doi.org/10.21098/jimf.v3i0.909

Sarwar, H., Khan, B., Nadeem, K., \& Aftab, J. (2016). Human Capital, HRM Practices and Organizational Performance in Pakistani Construction Organizations: The Mediating Role of Innovation. Archives of Business Research, 4(6), 72-82. https://doi.org/10.14738/ abr.46.2413

Shahid, H., ur Rehman, R., Niazi, G. S. K., \& Raoof, A. (2010). Efficiencies Comparison of Islamic and Conventional Banks of Pakistan. International Research Journal of Finance and Economics, 49, 24-44.

Smith, K. G., Collins, C. J., \& Clark, K. D. (2005). Existing Knowledge, Knowledge Creation Capability, and the Rate of New Product Introduction in High-Technology Firms. Academy of Management Journal, 48(2), 346-357. https://doi.org/10.5465/ AMJ.2005.16928421

Soleh, I. (2016). The Impact of Maqashid Syariah and Core Competency on Performance of Islamic Bank. International Journal of Economics, Commerce and Management United Kingdom, IV(10). 872-880.

Swanson, R. A., \& Chermack, T. J. (2013). Theory Building in Applied Disciplines. California: Berrett-Koehler Publishers.

Venkatraman, N., \& Ramanujam, V. (1986). Measurement of Business Performance in Strategy Research: A Comparison of Approaches. Academy of Management Review, 11(4), 801-814. https://doi.org/10.5465/amr.1986.4283976

Weng, W. (2019). Saudi Arabia Tops Islamic Bank Ranking, Malaysia Dominates Share of Assets.

Retrieved from: https://www.theasianbanker.com/updates-and-articles/saudi-arabiatops-islamic-bank-ranking,-malaysia-dominates-share-of-assets\#:-:text=Malaysia $\% 2$ C\%20Saudi\%20Arabia\%2C\%20UAE\%2C,the\%20100\%20largest\%20Islamic\%20 banks.

Yamin, S., Mavondo, F., Gunasekaran, A., \& Sarros, J. C. (1997). A Study of Competitive Strategy, Organizational Innovation and Organizational Performance Among Australian Manufacturing Companies. International Journal of Production Economics, 52(1-2), 161-172. https://doi.org/10.1016/S0925-5273(96)00104-1

Yudistira, D. (2004). Efficiency in Islamic Banking: an Empirical Analysis of Eighteen Banks. Islamic Economic Studies, 12-1(1), 2-19. 